\title{
Sediment Quality of Orashi River at Four Oil Producing Communities of Nigeria
}

\author{
AKACHUKWU, D; *NNAJI, JC; OJIMELUKWE, P., ONOJA, S; ODO, S \\ Michael Okpara University of Agriculture, Umudike, Abia State, Nigeria \\ *Corresponding Author Email: nnaji.jude@mouau.edu.ng
}

\begin{abstract}
Bed Sediment samples were collected in the Dry Season from Orashi River at three sampling sites each located in Mmahu, Opuoma, Abacheke and Ogwu Aniocha communities. Physicochemical parameters, hydrocarbon and heavy metal ( $\mathrm{As}, \mathrm{Cd}, \mathrm{Fe}$ and $\mathrm{Pb}$ ) concentrations were determined with standard methods. Results showed that total petroleum hydrocarbon (TPH) ranged from $0.11 \pm 0.03$ to $1.91 \pm 0.25 \mathrm{mg} / \mathrm{kg}$ while total hydrocarbon content (THC) and oil and grease had ranges of $0.28 \pm 0.06-2.98 \pm 0.19$ and 0.69 $\pm 0.09-3.60 \pm 0.57$ $\mathrm{mg} / \mathrm{kg}$ respectively. The sediment samples were classified as unpolluted in terms of TPH. Mean values for $\mathrm{pH}$ had a range of $4.33 \pm 0.22-6.60 \pm 0.52$ while the texture of most samples was sandy. Mean organic carbon contents ranged from $0.58 \pm 0.07$ to $3.15 \pm 0.66 \%$ and mean total nitrogen and total phosphorus had ranges of $0.30 \pm 0.00$ $2.77 \pm 0.46$ and $17.34 \pm 1.65-29.48 \pm 1.63 \mathrm{mg} / \mathrm{kg}$ respectively. Mean $\mathrm{Mg}$ concentrations were significantly higher $(\mathrm{P}<0.05)$ than the concentrations of other exchangeable bases and mean As concentration had a range of $1.175 \pm 0.086-1.291 \pm 0.335 \mathrm{mg} / \mathrm{kg}$. Mean Cd concentrations ranged from $0.948 \pm 0.072$ to $3.120 \pm 0.131 \mathrm{mg} / \mathrm{kg}$ while mean $\mathrm{Fe}$ and $\mathrm{Pb}$ concentrations had ranges of $57.324 \pm 10.530-159.707 \pm 41.192$ and $1.300 \pm 0.295-7.462 \pm 0.861 \mathrm{mg} / \mathrm{kg}$ respectively. As and $\mathrm{Pb}$ values were lower than the sediment quality guidelines (SQG) but $\mathrm{Cd}$ values were higher than the guidelines in all sites. Contamination factors ( $\mathrm{CFs}$ ) for As and $\mathrm{Pb}$ indicated low contamination while $\mathrm{CFs}$ for $\mathrm{Cd}$ indicated moderate to considerable contamination. Geo-accumulation index (Igeo) values for $\mathrm{As}$ and $\mathrm{Pb}$ at all sites and that of $\mathrm{Cd}$ at one site indicated unpolluted, Igeo values for $\mathrm{Cd}$ at all other sites ranged between 0.210 and 1.571 indicating unpolluted to moderately polluted status.
\end{abstract}

\section{DOI: https://dx.doi.org/10.4314/jasem.v24i7.4}

Copyright: Copyright $(C 2020$ Akachukwu et al. This is an open access article distributed under the Creative Commons Attribution License (CCL), which permits unrestricted use, distribution, and reproduction in any medium, provided the original work is properly cited.

Dates: Received: 11 May 2020; Revised: 22 June 2020; Accepted: 07 July 2020

Keywords: Sediment, Orashi, hydrocarbons, physicochemical, metals, contamination

Anthropogenic activities like oil and gas production results in the production of pollutants like petroleum hydrocarbons and trace metals which contaminate environmental matrices. Studies have revealed that subtle changes which occur in aquatic and terrestrial ecosystems of the Niger Delta correlate with petroleum activities and it affects human health, ecosystems, cultural and historical resources (Ogbeibu et al., 2018; Nwachukwu and Osuagwu, 2014). Oil and gas companies like Shell Petroleum Development Company (SPDC), Nigerian Agip Oil Company (NAOC) and Nigeria Petroleum Development Company (NPDC) operate in Ohaji-Egbema Local Government Area (LGA) of Imo State. Their operations results in oil spill incidences and gas flaring which can potentially pollute the environment (Rainforest News, 2010; Daily Post, 2015). Oil companies like Orient Petroleum, Oil Indian and Sterling Oil E\&P Production Co. Ltd (SEEPCO) also operate in Ogwu Aniocha, Ogwu Ikpele and Usham, all in Ogbaru LGA of Anambra State (Sun News 2019; Business and Maritime West Africa, 2019). On entry into waterbodies, pollutants are partitioned between water, sediments, suspended solids and aquatic biota and they tend to accumulate more in sediments than in water and aquatic organisms (Kumar et al., 2010; Umesi et al., 2013). Study of bed sediments of a waterbody is important since it serves as a sink for metals and other materials which are also remobilized from sediments into the overlying water column depending on $\mathrm{pH}$ and other conditions. Bottom sediment analysis give an idea of the history of contamination and the types of contaminants present in water (Araujo et al., 1988; Zvinowanda et al., 2009). In addition, the overlying water is in dynamic equilibrium with sediment and the quality of sediment influences the biological productivity of waterbodies (Gupte and Shaikh, 2014). Due to the paucity of data, the aim of this study was to determine the quality of sediments collected from sites on Orashi River located at Mmahu, Opuoma, Abacheke and Ogwu Aniocha communities.

\section{MATERIALS AND METHODS}

Description of Study Areas: Orashi or Ulasi River is located in the lower Niger River basin and it is a tributary of Oguta Lake flowing through Anambra, 
Imo, Bayelsa and Rivers States, Nigeria. The source of Orashi River is the rocks of Ezeama community of Dikenafai, Imo State which is $183 \mathrm{~m}$ above mean sea level. From Dikenafai, it flows through communities like Urualla, Ozubulu, Oguta, Opuoma, Mmahu, Abacheke, Omoku and Epie before emptying into the Atlantic Ocean (Alchetron, 2018). Opuoma, Mmahu and Abacheke are in Ohaji-Egbema Local Government Area (LGA) of Imo State. At Ozubulu, Orashi takes a left turn and flows through Okija but a westerly course flows through communities like Ogwu-Aniocha and Ogwu-Ikpele in Ogbaru LGA in Anambra State. Orashi R. splits into two at Egbema in Rivers State with the larger right portion flowing through Eluku before splitting again into two and emptying into the Gulf of Biafra. The Orashi Region is home to over $35 \%$ of the oil wells in the Niger Delta States of Imo and Rivers.

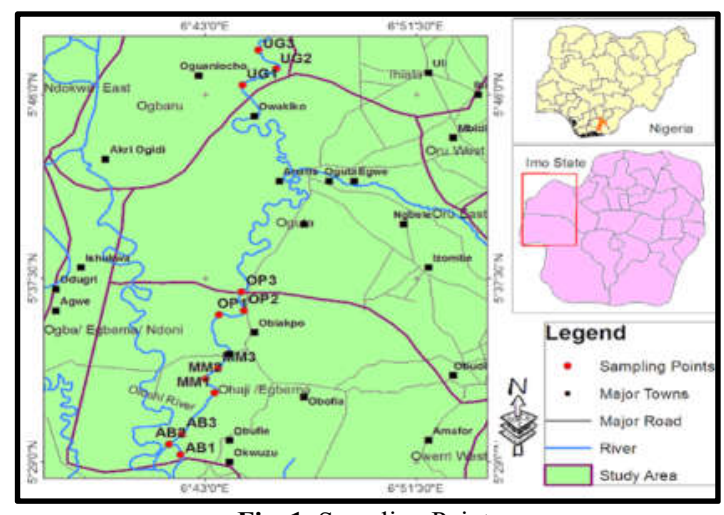

Fig. 1. Sampling Points

Table 1. GPS Coordinates of the Sampling Points

\begin{tabular}{|c|c|c|c|}
\hline \multirow[t]{2}{*}{ LOCATION } & \multirow{2}{*}{$\begin{array}{l}\text { SAMPLE } \\
\text { 1D }\end{array}$} & \multicolumn{2}{|c|}{ COORDINATES } \\
\hline & & Easting & Northing \\
\hline Abacheke 1 & $\mathrm{AB} 1$ & $00642 " .272$ & $0530 " .779$ \\
\hline Abacheke 2 & $\mathrm{AB} 2$ & $00642 " .379$ & $0530 " .795$ \\
\hline Abacheke 3 & AB3 & $00642 " .688$ & $0530 " .015$ \\
\hline Mmahu 1 & MM1 & $00643 " .843$ & $0533 " .815$ \\
\hline Mmahu 2 & MM2 & $00643 " .878$ & $0533 " .923$ \\
\hline Mmahu 3 & MM3 & 00643 ".908 & $0533 " .966$ \\
\hline Opuoma 1 & OP1 & $00644 " .511$ & $0536 " .273$ \\
\hline Opuoma 2 & OP2 & $00644 " .565$ & $0536 " .205$ \\
\hline Opuoma 3 & OP3 & $00644 " .586$ & $0536 " .058$ \\
\hline Ogwu-Aniocha 1 & UG1 & $00644 " .146$ & 05 47".156 \\
\hline Ogwu-Aniocha 2 & UG2 & $00645 " .095$ & $0547 " .759$ \\
\hline Ogwu-Aniocha 3 & UG3 & $00645^{\prime \prime} .224$ & $0548 " .172$ \\
\hline
\end{tabular}

Sampling: Triplicate bed sediment samples were collected in the Dry Season with Eckman Grab sampler from 12 sampling sites (Fig. 1) in Mmahu, Opuoma, Abacheke (Ohaji/Egbema LGA) and Ogwu Aniocha (Ogbaru LGA) at three different sites at each location: down-stream (point 1), mid-stream (point 2) and upstream (point 3). The samples were wrapped with polythene bags, kept in an ice chest followed by transportation to the laboratory for analysis. Coordinates of the study sites (Table 1) were measured with GRAMIN global positioning system (GPS) instrument.

Sample Pre-treatment: Extraneous materials were removed from sediment samples. All samples for organic carbon and heavy metal analyses were oven dried at $110^{\circ} \mathrm{C}$ while those for other analyses were air dried. Dry sediment samples from each treatment were ground into fine powder with acid washed plastic mortar and pestle. Samples from each treatment were divided into two and passed separately, through $2 \mathrm{~mm}$ and $0.2 \mathrm{~mm}$ sieves. They were then stored in dry acid washed polyethylene bottles with screw caps, at room temperature, prior to analyses. The $2 \mathrm{~mm}$ samples were used for the determination of $\mathrm{pH}$, total phosphorus, total nitrogen, particle size and exchangeable bases while the $0.2 \mathrm{~mm}$ samples were used for organic carbon, organic matter and metal analyses.

Determination of Physicochemical Parameters: The $\mathrm{pH}$ of the dry sediments was determined by inserting a pre-calibrated digital $\mathrm{pH}$ meter into a 1:2.5 sedimentdistilled water slurry and taking the reading. Organic carbon was determined by the wet-acid oxidation method (Walkey and Black, 1934). Organic Matter was analysed by ignition of the sample in a muffle furnace at $500{ }^{\circ} \mathrm{C}$ for $4 \mathrm{~h}$ and subsequently cooling in a desiccator to achieve constant weight (Elith and Garwood, 2001). Total nitrogen (TN) was analyzed using the Kjeldahl method while total Phosphorus was analysed in each sample by digestion with perchloric acid, dilution of digest with distilled-deionised water, filtration of the resulting solution and utilization of the stannous chloride method to determine $\mathrm{P}$ in $\mathrm{mg} / \mathrm{kg}$ (Agbenin, 1995; APHA, 2012). Particle size analysis was done using the hydrometer method which utilizes $50 \%$ Calgon (sodium hexametaphosphate) as dispersing agent (Bouyoncus, 1951). Total exchangeable bases $(\mathrm{K}, \mathrm{Na}, \mathrm{Ca}$ and $\mathrm{Mg}$ ) were determined by the ammonium acetate $\left(\mathrm{NH}_{4} \mathrm{AOC}\right)$ extraction method (Jackson, 1958). Sample (10 g) was extracted with $100 \mathrm{ml}$ of solvent mix (1:1 Hexane: Dichloromethane) in a soxhlet extractor and concentrated to $2 \mathrm{ml}$. The extract was passed through a packed and conditioned column containing glass wool, baked silica gel and anhydrous sodium sulphate at $105{ }^{\circ} \mathrm{C}$ with solvent to clean up the extract. $1 \mu \mathrm{L}$ of the extract was injected into and analysed for total petroleum hydrocarbons (TPH) with Agilent 7890A Gas Chromatography system with flame Ionization detector (GC-FID). Sample (10 g) was weighed into a soxhlet extractor thimble and $100 \mathrm{~mL}$ of tetrachloroethylene was added, refuxed three times before being concentrated with rotary evaporator. The extract was cleaned up with sodium sulphate 
anhydrous and glass wool. The cuvette of InfraCal 2 oil in water/soil Analyzer (Infra-Red spectrophotometer) was filled with the extract and oil and grease content $(\mathrm{O} \& \mathrm{G})$ was read after blanking with the extracting solvent. For total hydrocarbon content (THC), the extract was cleaned up with 100$200 \mathrm{~mm}$ mesh silica gel and anhydrous sodium sulphate before being analysed with InfraCal 2 analyzer. All analyses were done in triplicate.

Heavy Metal Analysis: Serial Dilution and Preparation of Calibration Curves: Stock solutions (1000 ppm) of the metal (Fe, $\mathrm{Pb}, \mathrm{Cd}$ and As) were prepared with the appropriate salts $\left[\mathrm{Cd}\left(\mathrm{NO}_{3}\right)_{2} \cdot 4 \mathrm{H}_{2} \mathrm{O}\right.$, $\mathrm{Pb}\left(\mathrm{NO}_{3}\right)_{2}, \mathrm{As}_{2} \mathrm{O}_{3}$ and $\left.\mathrm{Fe}\left(\mathrm{NO}_{3}\right)_{3}\right]$ of each metal. Five standard solutions of each metal were prepared from appropriate stock solution by serial dilution. The standards solutions were aspirated into a Flame Atomic Absorption Spectrophotometer (SpectrAA 100) and the absorbances obtained for the standard solutions of a particular metal were used in drawing calibration curves.

Digestion of Samples: Sample (5 g) of the sieved sediment sample was weighed with electronic weighing balance into a $100 \mathrm{ml}$ beaker and digested with $20 \mathrm{ml}$ mixed acids (1 perchloric acid:3 concentrated nitric acid). Anti-bump and $5 \mathrm{ml}$ of distilled/de-ionized water were added and the crucible was heated gently with a hotplate in a fume cupboard to partial dryness. The beaker was then allowed to cool and $10 \mathrm{ml}$ of distilled-deionized water was added. This was stirred gently with glass rod and filtered through Whatman No. 42 filter paper into a $50 \mathrm{ml}$ volumetric flask and made up to mark with distilled-deionized water

Method validation, Metal Analysis and Conversion of results: The procedure and method was validated by the use of a standard reference sample. This involved determining the metal concentrations in a standard reference food sample from International Atomic Energy Agency (IAEA) obtained through BGL Laboratories, Port-Harcourt. The standard reference material was digested and analyzed in triplicate with the methods used for the samples. The percentage recovery was calculated and the digested samples and blank solutions were aspirated in triplicate into the AAS instrument and the absorbance recorded. As was analyzed with the hydride generation accessory with closed end cell. Metal concentrations for the samples obtained from extrapolation on the calibration curves were in weight/volume basis $(\mathrm{mg} / \mathrm{L})$ and they were converted to weight/weight basis $(\mathrm{mg} / \mathrm{kg})$ using the formula:

$$
\text { Conc. }\left(\frac{\mathrm{mg}}{\mathrm{kg}}\right)=\frac{\left(\text { conc. } \frac{\mathrm{mg}}{\mathrm{L}} \times \text { dilution factor }\right)}{\text { wt of sample digested }(\mathrm{g})} \quad 1
$$

Dilution factor $=50=$ volume in $\mathrm{ml}$ of the digest solution

\section{Calculation of Metal Contamination Indices}

The indices calculated in this study were:

(a) Contamination factor (CF). This is expressed as;

$$
C F=\frac{C_{\text {heavy metal }}}{C_{\text {Target ref value }}} \quad 2
$$

Where $C_{\text {heavy metal }}$ is the concentration of a metal in the sample and $C_{\text {Target }}$ ref value is the background/recommended value for the metal in sediments.

(b) Pollution load index (PLI). PLI is expressed as (Tomilson et al., 1980);

$P L I=(C F 1 \times C F 2 \times C F 3 \ldots \ldots \ldots \times C F n)^{\frac{1}{n}}$

Where CFn is the CF value of metal, $n$.

(c) Geoaccumulation index (Igeo). The Igeo of the metals was calculated using the equation of Christophoridis et al. (2009):

$$
\text { Igeo }=\log _{2}\left(\frac{C_{n}}{1.5 B_{n}}\right)
$$

$(\mathrm{Cn}=$ measured concentration of metal in sediment, $\mathrm{Bn}=$ geochemical background criteria for sediment, 1.5 is a constant which allows for fluctuations of a given metal in the environment in addition to small anthropogenic influences.

\section{RESULTS AND DISCUSSION}

Table 2 shows the mean total petroleum hydrocarbon (TPH), total hydrocarbon content (THC) and oil and grease $(\mathrm{O} \& \mathrm{G})$ concentrations in the sediment samples. TPH ranged from $0.11 \pm 0.03$ at Opuoma site 2 (OP2) to $1.91 \pm 0.25 \mathrm{mg} / \mathrm{kg}$ at Ogwu Aniocha site 3 (OG3) while THC and O\&G had ranges of $0.28 \pm 0.06-2.98$ \pm 0.19 and $0.69 \pm 0.09-3.60 \pm 0.57 \mathrm{mg} / \mathrm{kg}$ respectively. Significantly higher values $(\mathrm{P}<0.05)$ for the three parameters were obtained in the three samples from Ogwu Aniocha compared to the samples from Mmahu, Opuoma and Abacheke. There are no national or international sediment quality guidelines for TPH, THC or O\&G but Massoud et al. (1996) and Ritchie et al. (2001) suggested four levels of pollution with respect to TPH pollution namely; unpolluted (10-15 $\mathrm{mg} / \mathrm{kg})$, slightly polluted $(15-50 \mathrm{mg} / \mathrm{kg})$, moderately 
polluted $(50-200 \mathrm{mg} / \mathrm{kg})$ and heavily polluted $(>200$ $\mathrm{mg} / \mathrm{kg}$ ).

Table 2. Mean $( \pm \mathrm{SD}) \mathrm{TPH}, \mathrm{THC}$ and Oil \& Grease Contents of Sediment Samples

\begin{tabular}{llll}
\hline $\begin{array}{l}\text { Sample } \\
\text { ID }\end{array}$ & $\begin{array}{l}\text { TPH } \\
(\mathbf{m g} / \mathbf{k g})\end{array}$ & $\begin{array}{l}\mathbf{T H C} \\
(\mathbf{m g} / \mathbf{k g})\end{array}$ & $\begin{array}{l}\text { Oil \& Grease } \\
(\mathbf{m g} / \mathbf{k g})\end{array}$ \\
\hline $\mathrm{MM} 1$ & $0.25 \pm 0.11^{\mathrm{a}}$ & $0.56 \pm 0.07^{\mathrm{a}}$ & $0.72 \pm 0.15^{\mathrm{a}}$ \\
$\mathrm{MM} 2$ & $0.31 \pm 0.09^{\mathrm{a}}$ & $0.87 \pm 0.22^{\mathrm{b}}$ & $1.30 \pm 0.24^{\mathrm{b}}$ \\
$\mathrm{MM} 3$ & $0.19 \pm 0.05^{\mathrm{b}}$ & $0.59 \pm 0.09^{\mathrm{a}}$ & $0.81 \pm 0.16^{\mathrm{a}}$ \\
$\mathrm{OP} 1$ & $0.15 \pm 0.01^{\mathrm{b}}$ & $0.32 \pm 0.11^{\mathrm{c}}$ & $0.42 \pm 0.05^{\mathrm{c}}$ \\
$\mathrm{OP} 2$ & $0.11 \pm 0.03^{\mathrm{b}}$ & $0.28 \pm 0.06^{\mathrm{c}}$ & $0.45 \pm 0.12^{\mathrm{c}}$ \\
$\mathrm{OP} 3$ & $0.20 \pm 0.07^{\mathrm{b}}$ & $0.52 \pm 0.16^{\mathrm{a}}$ & $1.33 \pm 0.14^{\mathrm{b}}$ \\
$\mathrm{AB} 1$ & $0.24 \pm 0.04^{\mathrm{a}}$ & $0.53 \pm 0.09^{\mathrm{a}}$ & $0.69 \pm 0.09^{\mathrm{a}}$ \\
$\mathrm{AB} 2$ & $0.28 \pm 0.08^{\mathrm{a}}$ & $0.61 \pm 0.13^{\mathrm{a}}$ & $1.07 \pm 0.06^{\mathrm{b}}$ \\
$\mathrm{AB} 3$ & $0.17 \pm 0.02^{\mathrm{b}}$ & $0.46 \pm 0.08^{\mathrm{a}}$ & $0.65 \pm 0.02^{\mathrm{a}}$ \\
OG1 & $0.94 \pm 0.40^{\mathrm{c}}$ & $2.06 \pm 0.42^{\mathrm{d}}$ & $2.68 \pm 0.33^{\mathrm{d}}$ \\
OG2 & $1.53 \pm 0.38^{\mathrm{c}}$ & $2.55 \pm 0.37^{\mathrm{d}}$ & $3.11 \pm 0.61^{\mathrm{e}}$ \\
OG3 & $1.91 \pm 0.25^{\mathrm{d}}$ & $2.98 \pm 0.19^{\mathrm{e}}$ & $3.60 \pm 0.57^{\mathrm{e}}$ \\
\hline MM Mmahu, OP $=$ Opuoma, AB $=$ Abacheke, OG $=$ Ogwu \\
Aniocha; Values with the same superscript on the same column were \\
similar $(P>0.05)$
\end{tabular}

Based on this, the sediment samples collected from the 12 sampling sites in the four stations can be regarded as unpolluted in terms of TPH. Adeniji et al. (2017) in a study of Algoa Bay, South Africa observed that $\mathrm{pH}$ concentrations in the sediment samples ranged from 0.72 to $27.03 \mathrm{mg} / \mathrm{kg}$ (dry weight basis) while Inyang et al. (2018) obtained TPH concentration range of 270$830 \mathrm{mg} / \mathrm{kg}$ in the sediment samples of Qua-Iboe River, Akwa-Ibom State. These values were much higher than the TPH values obtained in this study. Seiyaboh et al. (2016) analyzed Orashi River sediment samples collected from five sampling stations within Rivers State and obtained a THC range of $4.96-9.62 \mathrm{mg} / \mathrm{kg}$ which is much higher than the range for this study. The mean physicochemical parameters of the sediment samples are shown in Table 3. Mean values for $\mathrm{pH}$, with a range of $4.33 \pm 0.22-6.60 \pm 0.52$, were mostly in the acidic region while particle size analysis indicated that the texture of most samples was sand. Verla et al. (2019) obtained a pH range of 6.81-7.55 in the sediments of Orashi River at its confluence with Oguta Lake in Oguta LGA of Imo State. Mean organic carbon content had a range of $0.58 \pm 0.07-3.15 \pm 0.66$ $\%$ while mean organic matter content ranged from $0.65 \pm 0.02$ to $4.64 \pm 0.73$. Mean values for total nitrogen and total phosphorus had ranges of $0.30 \pm 0.00$ $2.77 \pm 0.46$ and $17.34 \pm 1.65-29.48 \pm 1.63 \mathrm{mg} / \mathrm{kg}$ respectively. Seiyaboh et al. (2016) recorded a range of $2.51-4.01 \mathrm{mg} / \mathrm{kg}$ in dry season for total nitrogen for sediments of Orashi River which is higher than the values for this study. Exchangeable bases $(\mathrm{K}, \mathrm{Na}, \mathrm{Ca}$ and $\mathrm{Mg}$ ) were present in all the samples from all the sites and had ranges of $0.04 \pm 0.00-0.15 \pm 0.03$ for $\mathrm{K}$, $0.21 \pm 0.03-0.36 \pm 0.02$ for $\mathrm{Na}, 0.40 \pm 0.01-1.65 \pm 0.03$ for $\mathrm{Ca}$ and $4.11 \pm 0.53-10.84 \pm 1.72 \mathrm{Cmol} / \mathrm{kg}$ for $\mathrm{Mg}$. Mean $\mathrm{Mg}$ concentrations were significantly higher $(\mathrm{P}<0.05)$ than the concentrations of other exchangeable bases in all the samples. The heavy metal concentrations are shown in Table 4. As was detected in samples from only three sites with a range of $1.175 \pm 0.086$ $1.291 \pm 0.335 \mathrm{mg} / \mathrm{kg}$. The soil quality guidelines (SQG) for As is $7.24 \mathrm{mg} / \mathrm{kg}$ and this was much higher than all the mean values recorded for all the samples. Mean Cd concentrations ranged from $0.948 \pm 0.072$ to $3.120 \pm 0.131 \mathrm{mg} / \mathrm{kg}$ which were higher than the ISQG guideline value of $0.7 \mathrm{mg} / \mathrm{kg}$. Ranges for mean $\mathrm{Fe}$ and $\mathrm{Pb}$ concentrations were 57.324 \pm 10.530 $159.707 \pm 41.192$ and $1.300 \pm 0.295-7.462 \pm 0.861 \mathrm{mg} / \mathrm{kg}$ respectively. $\mathrm{Pb}$ concentrations were much lower than the SGQ value of $30.2 \mathrm{mg} / \mathrm{kg}$. Kpee and Ekpete (2014) in a study of sediment samples collected from Kalabari Creeks recorded mean values of 4,767.06 \pm 076.5 $\mathrm{mg} / \mathrm{kg}$ for $\mathrm{Fe}$ and $1.63 \pm 1.16 \mathrm{mg} / \mathrm{kg}$ for $\mathrm{Pb}$. Mean $\mathrm{Fe}$ values for this study were lower than theses values but mean $\mathrm{Pb}$ values were similar to their values. Verla et al. (2019) obtained a range of 0.04-0.09 and 0.28-0.99 $\mathrm{mg} / \mathrm{kg}$ for $\mathrm{Fe}$ and As concentrations respectively in the sediments of Orashi River at Oguta. These values were lower than the values for $\mathrm{Fe}$ and $\mathrm{As}$ in this study. Contamination factors (CF), geoaccumulation index (Igeo) and pollution load index (PLI) values are shown in Table 5. According to Hakanson (1980), range of values for $\mathrm{CF}$ are classified as follows: $\mathrm{CF}<1$ indicates low contamination; $1<\mathrm{CF}<3$ indicates moderate contamination; $3<\mathrm{CF}<6$ indicates considerable contamination and $\mathrm{CF}>6$ indicates very high contamination. $\mathrm{CFs}$ for $\mathrm{As}$ and $\mathrm{Pb}$ were all less than 1 at all the sites indicating low contamination. However, $\mathrm{CFs}$ for $\mathrm{Cd}$ were all greater than 1 with values at all sites in Ogwu Aniocha indicating considerable contamination while sites in Mmahu, Opuoma and Abacheke indicated moderate contamination except Abacheke site 2 with a value of 3.009 which also indicated considerable contamination. When PLI is greater than 1, the sediment is said to be polluted, PLI value equal to 1 signifies baseline level of pollution while PLI value less than 1 represents a non-polluted area. PLI values for all sites were all below 1 indicating that the sediments were not polluted with respect to the three heavy metals ( $\mathrm{As}, \mathrm{Cd}$ and $\mathrm{Pb}$ ). Classes of geo-accumulation index are (Huu et al., 2010); Igeo $<0=$ unpolluted, $0-1=$ unpolluted to moderately polluted, $1-2=$ moderately polluted, $2-3=$ moderately to strongly polluted, $3-4=$ strongly polluted, $4-5=$ strongly to extremely polluted and $>5$ $=$ extremely polluted. While the Igeo values for As and $\mathrm{Pb}$ at all sites and the Igeo values for $\mathrm{Cd}$ at the site MM2 were all below 0 indicating unpolluted, Igeo values for $\mathrm{Cd}$ at all other sites ranged between 0.210 and 1.571 indicating unpolluted to moderately polluted. 
Table 3. Mean $( \pm \mathrm{SD})$ Physicochemical Parameters of Sediment Samples

\begin{tabular}{|c|c|c|c|c|c|c|c|c|c|c|c|c|c|}
\hline \multirow{2}{*}{$\begin{array}{l}\text { Sample } \\
\text { ID }\end{array}$} & \multirow[t]{2}{*}{$\mathrm{pH}$} & \multicolumn{3}{|c|}{ Particle Size (\%) } & \multirow[t]{2}{*}{ Texture } & \multirow{2}{*}{$\begin{array}{l}\mathrm{OC} \\
(\%)\end{array}$} & \multirow{2}{*}{$\begin{array}{l}\text { OM } \\
(\%)\end{array}$} & \multirow{2}{*}{$\underset{(\mathrm{mg} / \mathrm{kg})}{\mathrm{TN}}$} & \multirow{2}{*}{$\underset{(\mathrm{mg} / \mathrm{kg})}{\mathrm{TP}}$} & \multicolumn{4}{|c|}{ Exchangeable bases (Cmol/kg) } \\
\hline & & Sand & Silt & Clay & & & & & & $\mathrm{K}$ & $\mathbf{N a}$ & $\mathrm{Ca}$ & $\mathrm{Mg}$ \\
\hline MMl & 4.81 & & 8.12 & 3.34 & Sand & & 1.4 & 0.32 & 21.54 & & 0.22 & & 4.85 \\
\hline $\mathrm{M} 2$ & & $\begin{array}{l} \pm 1.49^{1} \\
90.23 \\
\pm 2.81^{1}\end{array}$ & $\begin{array}{l} \pm 0.51^{1} \\
7.95 \\
\pm 0.88^{1}\end{array}$ & $\begin{array}{l} \pm 0.55^{\mathrm{A}} \\
1.82 \\
\pm 0.20^{\mathrm{b}}\end{array}$ & Sand & & & $\begin{array}{l}2.77 \\
\pm 0.46^{b}\end{array}$ & & $\begin{array}{l}01^{2} \\
6 \\
00^{2}\end{array}$ & & & $\begin{array}{l} \pm 0.01 \\
8.02 \\
\pm 1.30^{b}\end{array}$ \\
\hline $\mathrm{MMB}$ & $\begin{array}{l}5.80 \\
\pm 0.34^{b}\end{array}$ & $\begin{array}{l}80.61 \\
\pm 2.76^{b}\end{array}$ & & $\begin{array}{l}3.57 \\
\pm 0.47^{\circ}\end{array}$ & $\begin{array}{l}\text { Loamy } \\
\text { sand }\end{array}$ & & & & & & & & $\begin{array}{l}10.84 \\
\pm 1.72^{\mathrm{b}}\end{array}$ \\
\hline OP1 & & $\begin{array}{l}90.44 \\
\pm 3.25^{ \pm}\end{array}$ & & $\begin{array}{l}1.87 \\
\pm 0.21^{b}\end{array}$ & Sand & & & & & & & & $\begin{array}{l}6.43 \\
\pm 0.95^{2}\end{array}$ \\
\hline $\mathrm{OP} 2$ & $\begin{array}{l}5.57 \\
\pm 0.61^{1}\end{array}$ & $\begin{array}{l}78.62 \\
\pm 1.02^{\mathrm{b}}\end{array}$ & $\begin{array}{l}11.83 \\
\pm 1.07^{\star}\end{array}$ & $\begin{array}{l}9.55 \\
\pm 1.48^{d}\end{array}$ & $\begin{array}{l}\text { Loamy } \\
\text { sand }\end{array}$ & & & & & & & & $\begin{array}{l}6.80 \\
\pm 0.76^{2}\end{array}$ \\
\hline OP3 & $\begin{array}{l}5.21 \\
\pm 0.09^{ \pm}\end{array}$ & $\begin{array}{l}90.57 \\
\pm 4.21^{ \pm}\end{array}$ & $\begin{array}{l}6.14 \\
\pm 1.16\end{array}$ & $\begin{array}{l}3.29 \\
\pm 0.77^{1}\end{array}$ & Sand & & $\begin{array}{l}1.31 \\
\pm 0.05^{ \pm}\end{array}$ & $\begin{array}{l}0.55 \\
\pm 0.01^{2}\end{array}$ & $\begin{array}{l}17.34 \\
\pm 1.65^{\mathrm{b}}\end{array}$ & $\begin{array}{l}0.04 \\
\pm 0.00^{2}\end{array}$ & & $\begin{array}{l}1.63 \\
\pm 0.01^{b}\end{array}$ & $\begin{array}{l}8.00 \\
\pm 1.13^{\mathrm{b}}\end{array}$ \\
\hline$A B 1$ & $\begin{array}{l}5.85 \\
\pm 0.11^{\mathrm{b}}\end{array}$ & $\begin{array}{l}90.81 \\
\pm 1.86^{1}\end{array}$ & $\begin{array}{l}5.75 \\
\pm 0.69^{4}\end{array}$ & $\begin{array}{l}3.44 \\
\pm 0.28^{1}\end{array}$ & Sand & & & & & & & & $\begin{array}{l}6.42 \\
\pm 0.92^{1}\end{array}$ \\
\hline$A B 2$ & & $\begin{array}{r}92.34 \\
\pm 3.47^{ \pm}\end{array}$ & $\begin{array}{l}5.91 \\
\pm 0.44^{d}\end{array}$ & $\begin{array}{l}1.75 \\
\pm 0.11^{b}\end{array}$ & Sand & & $\begin{array}{l}1.01 \\
\pm 0.09^{\mathrm{b}}\end{array}$ & $\begin{array}{l}0.35 \\
\pm 0.01^{2}\end{array}$ & $\begin{array}{l}27.86 \\
\pm 3.15^{4}\end{array}$ & $\begin{array}{l}0.05 \\
\pm 0.01^{1}\end{array}$ & & & $\begin{array}{l}5.60 \\
\pm 0.87^{2}\end{array}$ \\
\hline AB3 & $\begin{array}{l}6.60 \\
\pm 0.52^{c}\end{array}$ & $\begin{array}{l}88.62 \\
\pm 1.53^{2}\end{array}$ & $\begin{array}{l}10.11 \\
\pm 0.86^{e}\end{array}$ & $\begin{array}{l}1.27 \\
\pm 0.09^{\prime}\end{array}$ & Sand & $\begin{array}{l}0.62 \\
\pm 0.10^{\text {b }}\end{array}$ & $\begin{array}{l}0.65 \\
\pm 0.02^{\mathrm{d}}\end{array}$ & $\begin{array}{l}0.50 \\
\pm 0.02^{2}\end{array}$ & & & & & $\begin{array}{l}4.11 \\
\pm 0.53^{2}\end{array}$ \\
\hline OGl & $\begin{array}{l}4.33 \\
\pm 0.22^{4}\end{array}$ & $\begin{array}{l}60.58 \\
\pm 1.77^{*}\end{array}$ & $\begin{array}{l}30.45 \\
\pm 2.70^{E}\end{array}$ & $\begin{array}{l}8.97 \\
\pm 1.25^{\mathrm{d}}\end{array}$ & $\begin{array}{l}\text { Sandy } \\
\text { loam }\end{array}$ & & & & $\begin{array}{l}21.49 \\
\pm 4.17^{1}\end{array}$ & & & & $\begin{array}{l}6.00 \\
\pm 1.25^{ \pm}\end{array}$ \\
\hline $\mathrm{OG} 2$ & $\begin{array}{l}5.08 \\
\pm 0.08^{1}\end{array}$ & $\begin{array}{l}40.37 \\
\pm 0.95^{\mathrm{a}}\end{array}$ & $\begin{array}{l}44.10 \\
\pm 2.13^{r}\end{array}$ & $\begin{array}{l}15.53 \\
\pm 2.16^{t}\end{array}$ & Silte & $\begin{array}{l}3.15 \\
\pm 0.66\end{array}$ & $\begin{array}{l}5.42 \\
\pm 0.88^{E}\end{array}$ & $\begin{array}{l}1.77 \\
\pm 0.05^{\circ}\end{array}$ & $\begin{array}{l}25.18 \\
\pm 3.01^{4}\end{array}$ & $\begin{array}{l}0.15 \\
\pm 0.03^{b}\end{array}$ & $\begin{array}{l}0.33 \\
\pm 0.03^{b}\end{array}$ & $\begin{array}{l}0.84 \\
\pm 0.05^{1}\end{array}$ & $\begin{array}{l}4.80 \\
\pm 0.81^{1}\end{array}$ \\
\hline OG3 & $\begin{array}{l}5.31 \\
\pm 0.14^{ \pm}\end{array}$ & $\begin{array}{l}70.66 \\
\pm 1.20^{\mathrm{b}} \\
\end{array}$ & $\begin{array}{l}12.39 \\
\pm 1.51^{\circ}\end{array}$ & $\begin{array}{l}16.95 \\
\pm 1.74^{t}\end{array}$ & $\begin{array}{l}\text { Sandy } \\
\text { loam }\end{array}$ & $\begin{array}{l}0.83 \\
\pm 0.05^{1}\end{array}$ & $\begin{array}{l}1.38 \\
\pm 0.11^{1}\end{array}$ & $\begin{array}{l}0.65 \\
\pm 0.02^{\mathrm{a}}\end{array}$ & $\begin{array}{l}24.16 \\
\pm 1.65^{\wedge} \\
\end{array}$ & $\begin{array}{l}0.10 \\
\pm 0.02^{\mathrm{b}}\end{array}$ & $\begin{array}{l}0.30 \\
\pm 0.04^{\mathrm{b}}\end{array}$ & $\begin{array}{l}0.40 \\
\pm 0.01^{c}\end{array}$ & $\begin{array}{l}7.64 \\
\pm 1.23^{2} \\
\end{array}$ \\
\hline
\end{tabular}

Values with the same superscript on the same column were similar $(\mathrm{P}>0.05)$

Table 4. Mean $( \pm \mathrm{SD})$ Heavy Metal Concentrations of Sediment Samples

\begin{tabular}{|c|c|c|c|c|}
\hline Sample ID & As (mg/L) & $\mathrm{Cd}(\mathrm{mg} / \mathrm{L})$ & $\mathrm{Fe}(\mathrm{mg} / \mathrm{L})$ & $\mathrm{Pb}(\mathrm{mg} / \mathrm{L})$ \\
\hline MM1 & ND & $1.215 \pm 0.301^{\mathrm{a}}$ & $57.324 \pm 10.530^{\mathrm{a}}$ & $3.502 \pm 0.877^{\mathrm{a}}$ \\
\hline MM2 & $1.175 \pm 0.086^{\mathrm{a}}$ & $0.948 \pm 0.072^{\mathrm{a}}$ & $104.902 \pm 14.810^{b}$ & $2.240 \pm 0.341^{\mathrm{b}}$ \\
\hline MM3 & ND & $1.413 \pm 0.438^{\mathrm{a}}$ & $130.231 \pm 23.720^{\mathrm{c}}$ & $4.311 \pm 0.826^{\mathrm{c}}$ \\
\hline OP1 & $1.283 \pm 0.250^{\mathrm{a}}$ & $2.523 \pm 0.197^{\mathrm{b}}$ & $95.022 \pm 21.164^{b}$ & $3.640 \pm 0.512^{\mathrm{a}}$ \\
\hline OP2 & ND & $2.216 \pm 0.066^{\mathrm{b}}$ & $101.100 \pm 18.355^{\mathrm{b}}$ & $1.610 \pm 0.762^{\mathrm{d}}$ \\
\hline OP3 & ND & $1.094 \pm 0.350^{\mathrm{a}}$ & $128.804 \pm 31.742^{\mathrm{c}}$ & $1.725 \pm 0.477^{\mathrm{d}}$ \\
\hline $\mathrm{AB} 1$ & ND & $1.547 \pm 0.204^{\mathrm{a}}$ & $81.646 \pm 12.774^{\mathrm{b}}$ & $2.633 \pm 0.396^{\mathrm{b}}$ \\
\hline $\mathrm{AB} 2$ & ND & $2.106 \pm 0.087^{\mathrm{b}}$ & $92.551 \pm 10.851^{\mathrm{b}}$ & $1.947 \pm 0.425^{\mathrm{e}}$ \\
\hline $\mathrm{AB} 3$ & $1.291 \pm 0.335^{\mathrm{a}}$ & $1.210 \pm 0.074^{\mathrm{a}}$ & $110.383 \pm 19.386^{b}$ & $7.462 \pm 0.861^{f}$ \\
\hline OG1 & ND & $3.120 \pm 0.131^{\mathrm{c}}$ & $102.301 \pm 24.470^{b}$ & $1.300 \pm 0.295^{\mathrm{d}}$ \\
\hline OG2 & ND & $2.409 \pm 0.088^{\mathrm{b}}$ & $121.174 \pm 25.310^{\mathrm{c}}$ & $2.324 \pm 0.814^{\mathrm{b}}$ \\
\hline OG3 & ND & $2.336 \pm 0.276^{\mathrm{b}}$ & $159.707 \pm 41.192^{\mathrm{c}}$ & $1.618 \pm 0.229^{\mathrm{d}}$ \\
\hline ISQG(mg/kg) & 7.24 & 0.7 & - & 30.2 \\
\hline
\end{tabular}

Values with the same superscript on the same column were similar $(P>0.05)$

Table 5. Contamination factors, Igeo and PLI values

\begin{tabular}{|c|c|c|c|c|c|c|c|}
\hline \multirow[t]{2}{*}{ Locations } & \multicolumn{3}{|c|}{ CF for Metals } & \multirow[t]{2}{*}{ PLI } & \multicolumn{3}{|c|}{ Igeo for Metals } \\
\hline & As & $\mathbf{C d}$ & $\mathbf{P b}$ & & As & Cd & $\mathbf{P b}$ \\
\hline MM1 & - & 1.736 & 0.116 & 0.449 & - & 0.210 & -3.699 \\
\hline MM2 & 0.162 & 1.354 & 0.074 & 0.253 & -3.211 & -0.147 & -4.351 \\
\hline MM3 & - & 2.019 & 0.143 & 0.537 & - & 0.429 & -0.157 \\
\hline OP1 & 0.177 & 3.604 & 0.121 & 0.426 & -3.083 & 1.264 & -3.626 \\
\hline OP2 & - & 3.166 & 0.053 & 0.410 & - & 1.078 & -4.837 \\
\hline OP3 & - & 2.233 & 0.057 & 0.357 & - & 0.574 & -4.718 \\
\hline $\mathrm{AB} 1$ & - & 2.210 & 0.087 & 0.438 & - & 0.559 & -4.108 \\
\hline AB2 & - & 3.009 & 0.064 & 0.577 & - & 0.419 & -4.540 \\
\hline AB3 & 0.178 & 1.728 & 0.247 & 0.424 & -3.071 & 0.204 & -2.599 \\
\hline OG1 & - & 4.457 & 0.043 & 0.438 & - & 1.571 & -5.108 \\
\hline OG2 & - & 3.441 & 0.077 & 0.515 & - & 1.198 & -4.293 \\
\hline OG3 & - & 3.337 & 0.054 & 0.424 & - & 1.154 & -4.796 \\
\hline
\end{tabular}

Conclusion: This study has shown that sediment samples collected from the four locations on Orashi River were unpolluted in terms of TPH and the texture of most bed sediment samples was sandy. Mean $\mathrm{As}$ and $\mathrm{Pb}$ concentrations were lower than the soil quality guidelines (SQG). However, mean Cd concentrations were higher than the guidelines in all sites and contamination factors also indicated moderate to considerable Cd contamination in the sediments. Geoaccumulation indices (Igeo) also indicated unpolluted to moderately polluted $\mathrm{Cd}$ status for the samples. 


\section{REFERENCES}

Adeniji, AO; Okoh, OO; Okoh, AI (2017). Petroleum Hydrocarbon Profiles of Water and Sediment of Algoa Bay, Eastern Cape, South Africa. Int. J. Environ. Res. Public Health 14: 1263-1284

Agbenin, JO (1995). Laboratory Manual for Soil and Plant Analysis. Dept. of Soil Science, Ahmadu Bello University, Zaria. Pp. 30-72.

Alchetron (2018). Orashi River. https://alchetron.com/Orashi-River Accessed $6^{\text {th }}$ January, 2020

APHA (2012). Standard Methods for the Examination of Water and Waste Water, 22nd Edition. American Public Health Association, American Water Works Association, Water Environment Federation, Washington DC

Araujo, MF; Bernard, PC; Van Grieken, RE (1988). Heavy metal contamination in sediments from the Belgian Coast and Sheldt Estuary. Mar. Poll. Bull. 19: $269-273$

Business and Maritime West Africa (2019). Upgrade your Licenses or leave Anambra, HOSCON Tells Orient Petroleum, 2 Others. https://businessandmaritimewestafrica.com/upgrad e-your-licenses-or-leave-anambra-hoscon-tellsorient-petroleum-2-others/ Accessed 25 ${ }^{\text {th }}$ March, 2020

Daily Post (2015). Agip Oil Spill: Multinational Oil Companies lack respect for host communities-Hon. Opia. https://dailipost.ng/2015/08/08/agip-oil-spillmultinational-oil-companies-lack-respect-for-hostcommunities-hon-opiah/ Accessed 30 ${ }^{\text {th }}$ March, 2020

Bouyoncos, GH (1951). Determination of particle sizes in soils. Agro. J. 43: 434-438

Canadian Council of Ministers of the Environment (1999). Canadian sediment quality guidelines for the protection of aquatic life: Canadian Council of Ministers of the Environment, Winnipeg.

Christophoridis, C; Dedepsidis, D; Fytianos, K (2009). Occurrence and Distribution of selected Heavy Metals in the Surface Sediments of Thermaikos Gulf, N. Greece. Assessment using Pollution Indicators. J. Haz. Mat. 168:1082-1091

Elith, M; Garwood, S (2001). Investigations into the levels of Heavy metals within Manly Dam catchment. Freshwater Ecology Report 2001. Department of Environmental Sciences, University of Technology, Sydney

Gupte, A; Shaikh, N (2014). Sediment Analysis of Shelar Lake, Maharashtra. Global J. Sc. Front. Res.: H Environ. Earth Sc. 14(3): 10-15

Hakanson, L (1980). An ecological risk index for aquatic pollution control: a Sedimentological approach. Water Res. 14: 975-1001

Huu, HH; Rudy, S; Damme, AV (2010). Distribution and contamination status of heavy metals in estuarine sediments near Cau Ong Harbor, Ha Long Bay, Vietnam. Geologica Belgica, 13: 37-47.

Inyang, SE; Aliyu, AB; Oyewale, AO (2018). Total Petroleum Hydrocarbon Content in Surface Water and Sediment of Qua-Iboe River, Ibeno, AkwaIbom State, Nigeria. J. Appl. Sci. Environ. Manage. 22(12): 1953-1959

Jackson, MLC (1958). Soil Chemical Analysis Practice. Halline Eagle Wood Cliff Ltd, New Jersey.

Kpee, F; Ekpete, OA (2014). Levels of Trace Metals in Surface Sediments from Kalabari Creeks, Rivers State, Nigeria. J. Appl. Sci. Environ. Manage. 18(2): 189-195

Kumar, B; Kumar, KS; Priya, M; Mukhopadhyay, D; Shah, R (2010). Distribution, partitioning, bioaccumulation of trace elements in water, sediment and fish from sewage fed fish ponds in eastern Kolkata, India. Tox. Environ. Chem. 92(2): 243-260

Massoud, MS; Al-Abdali, F; Al-Ghadban, AN; AlSarawi, M (1996). Bottom sediments of the Arabian Gulf-II. TPH and TOC contents as indicators of oil pollution and implications for the effect and fate of the Kuwait oil slick. Environ. Pollut. 93: 271-284

Nwachukwu, AN; Osuagwu, JC (2014). Effects of Oil Spillage on Groundwater Quality in Nigeria. Amer. J. Eng. Res. 3(6): 271-274.

Ogbeibu, AE; Zagi, MM; Balogun, AA (2018). Harmonization of Environmental Report Structures for the Oil and Gas Industry in Nigeria. Proceedings of the 18th International HSE Biennial Conference on the Oil \& Gas Industry in Nigeria. Pp. 71-105

Rainforest News (2010). Agip causes spill at the Abacheke Community www.salvaleforeste.it/en/home-2/72-news/eco- 
justice/2146-nigeria-agip-causes-oil-spill-at-theabacheke-community.html Accessed 30 ${ }^{\text {th }}$ March, 2020

Ritchie, DG; Still, RK; Alexander, KW (2001). A review of the neurotoxicity risk of selected hydrocarbon fuels. J. Toxicol. Environ. Health 4(3):223-312

Tomilson, DC; Wilson, JG; Harris, CR; Jeffrey, DW (1980). Problems in assessment of heavy metals in estuaries and the formation of pollution index. Helgoland Mar. Res. 33(1-4): 566-575

Seiyaboh, EI; Alagha, WE; Angaye, TCN (2016). Sedimentary Assessment of Basic River in the Niger Delta: A Case Study of Orashi River in the Eastern Niger Delta of Nigeria. Greener J. Geo. Earth Sc. 4 (3): 051-055

Sun News (2019). Accord Anambra oil-producing status now, host communities charge FG. https://sunnewsonline.com/accord-anambra-oilproducing-status-now-host-communities-charge-fg/ Accessed 2 ${ }^{\text {nd }}$ April, 2020
Umesi, N; Disiru, CNG; Nwogbidi, KC: Wokoma, OAF (2013). Effects of Organic Carbon on Diversity of Littoral Benthos in Sites around the Rumueme Creek in the Upper Bonny Estuary. Asian J. Nat. Appl. Sc. 2. 31-40

Verla, AW; Enyoh, CE; Verla, EN; Okeke, PN; Shirish, SP (2019). Chemometric Assessment of Orashi River after Confluence with Oguta Lake. Indones. J. Fundam. Appl. Chem. 4(3): 91-103

Walkey, A; Black AI (1934). An Examination of the Detiare Method of Determining Soil Organic Matter and Proposed Modification of the Chronic Acid and Titration. Soil Sc. 37: 29-36.

Zvinowanda, CM; Okonkwo, JO; Shabalala, PN; Agyei, NM (2009). A novel adsorbent for heavy metal remediation in aqueous environments. Int. $J$. Environ. Sci. Tech. 6(3): 425-434 